\title{
メタノール中における $\mathbf{N} \cdot \boldsymbol{N}$-ジメチルアニリンの電解酸化* （I）クリスタルバイオレットの生成
}

安河内一夫块, 武藤博***

\section{Electrolytic Oxidation of $N \cdot N$-Dimethylaniline in Methanol* \\ (I) Preparation of Crystal Violet}

\author{
Kazuo Yasukouchi** and Hiroshi Mutou***
}

\begin{abstract}
The electrolytic oxidation of $N \cdot N$-dimethylaniline was studied for the purpose of the synthesis of triphenylmethane dyes. Methanol was used as the solvent for its ability to serve as the center carbon of triphenylmethane dyes. Hydrogen chloride was used as a supporting electrolyte and saltforming agent. Crystal violet, one of the triphenylmethane dyes, was formed at hydrogen chloride concentrations of $0.5 \sim 0.15 \mathrm{M}$. Quantitative studies of each factor, i.e. amount of contained water, concentration of hydrogen chloride, temperature, current density, quantity of electricity, were carried out to $\mathrm{rise}$ the yield of crystal violet and to investigate the formation mechanism. The best yield of crystal violet was about $1.8 \%$, and the main product was $N \cdot N$-tetramethylbenzidine (TMB). A formation scheme of crystal violet consisting of electrode and chemical processes is proposed.
\end{abstract}

\section{1 緒 言 (Introduction)}

有機溶媒中での電解酸化反忘の研究の一環として,

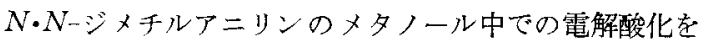
試みた・ジチルアニリンの電解酸化についての報告 は, 最初 Löb がク口ム酸を添加した硫酸酸性水溶液中 で $N \cdot N^{\prime}$-テトラメチルベンジジン1)，ついでFichter ら が硫酸酸性水溶液中で主生成物としてテトラメチルベン ジジ，副生成物として 4.4'-ビスージメチルアミノジ フェニルメタンの生成を確認している尚. また化学的酸 化についての報告では Nayler らが過酸化水素による酸 化によって微量のトリフェニルメタン系色素と推定され る色素死得ているし ロルアニルまたはクロルアニルと塩化第一銅とによる酸 化によってタリスタルバイオレットとメチルバイオレッ トの混合物が生成することを確認している4,5)。さらに 最近で活 Weinberg らがメタノール中で電解酸化を行 い，支持電解質として硝酸アンモニウムを用いるとテト

* 有譏化合物の) 電解酸化 (第 1 芣) Electrolytic Oxidation of Or ganic Compounds (Part 1) 昭和 44 年 6 月電気化学拹会第 $36 \mid$ 叫 大会 (横浜) 16 一部発淁

** 熊本大学工学部(熊本市黑翼町)

Department of Industrial Chemistry, Faculty of Engineering. Kumamoto University (Kumamoto)

**** 九州大等薬学部(福同南大字堅粕)

Faculty of Pharmaceutical Sciences Kyushu University (Fukuoka)
ラメチルベンジジンが生成するが，水酸化力リウムを 用いるとメトキシ化合物が生成することを確認してお

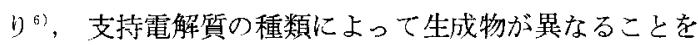
示唆している.

これらの報告から電解条件によってはジメチルアニリ ンの酸化によってトリフェニルメタン系色素を生成する ことも可能であり，しかも通常の化学反応においてジメ チルアニリンからトリフェニルメタン色素合成する場 合とは異なり，適当な中心炭素源を共存させると卜リフ エニルメタン系色素クリスタルバイオレットのみが生成 寸ると推測した。 そこで溶媒として色素の中心炭素源之 なる可能性をるつメタノールを用い，支持電解質として 生成色素造塩剤をか㸚，しかもメ夕ノール中で相当解離 する乾燥塩化水素を用いて，クリスタルバイオレットの 生成について検討した。

\section{2 実 験 (Experimental)}

\section{1 試料およひ試暞}

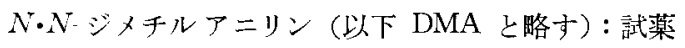
特級品.

メ夕ノール：試楽一級品を脱水蒸留.

塩化水素-メタノール溶液：塩化ナトリウムに濃硫酸 存滴下し, 発生する塩化水素ガスを濃硫酸で脱水した後, メ夕ノールに吸収させた。

カールフィッシャ一氷分定量試薬 : 三菱化成製 
$N \cdot N^{\prime}$-テトラメチルベンジジン（以下 TMB と略す）： Fichter らの方法”により電解合成し，エタノールより 3 回再結晶. m.p. $197 \sim 198^{\circ} \mathrm{C}$.

4・4'ービメージメチルアミノジフェニルメタン（以下テ トラベースと略す）：DMA とホルムアルデヒドを硫酸 酸性で縮合させ，水酸化ナトりウム溶液でアルカリ性と し，水蒸気蒸留により末反応の DMA を除いたのちエ夕 ノール上り 4 回再結晶. m.p. $91^{\circ} \mathrm{C}$.

4.4'-ビスージメチルアミノジフェニルベンツヒドロー ル（以下ミヒラヒドロールと略す）：テトラベースを硝 酸酸性とし, $\mathrm{PbO}_{2}$ による酸化を行い, 得られたミ七ラ ヒドロールをメタノールより 3 回再結晶. m.p. $96^{\circ} \mathrm{C}$.

クリスタルバイオレット(以下 $\mathrm{CV}$ と略す), メチル バイオレット (以下 $\mathrm{MV}$ 上略す)：試薬特級品.

\section{2 実験菨置}

電解ビンは防湿用のシリカゲルカラムをつけた，内容 積 $100 \mathrm{~m} l$ のガラス製，両極泣ともに主として白金板 (有効表面積 $10 \mathrm{~cm}^{2}$ ), ほかに炭素, モリブデン, タング ステン，グラシーカーボンを用い，かきまぜはマグネチ ックスターラー, 温度の調節は恒温水を通して行った。 定電流電源は柳本定電位電解装置 VE 3 型, 電解液の含 水量は筒井化学ミクロカールフィッシャ一電気滴定装置 で定量した．可視および紫外吸収スペクトルは日立自記 分光光度計 EPS-2 型で測定, また口紙電気泳動は東洋 口紙電気泳動装置, 溶液中でのラジカルイオンの測定は 日本電子 JES-3 BSX を使用した。

\section{3 電解液の処理}

DMA $6.1 \mathrm{~g}(0.05$ モル) 塩化水素メタノール溶液 $70 \mathrm{~m} l$ にとかし電解液上した. 電解液はほとんど無色で あるが: 電解を開始するとすぐに淡黄色となりしだいに 黄加色, 緑色へと变化し, 沈殿が析出し始め, さらに 紫色へと変化した。電解終了後, 沈殿を漏別し漏液を又 タノールで希釈し, 正確に $100 \mathrm{ml}$ とし, これをメタノ ールで 2500 倍あるいは 5000 倍に希釈したのち色素の 定量を行った。

\section{4 生成物の確認}

電解生成物中の沈䟝は混融法および赤外吸収スペクト ル，紫外吸収スペクトルによる同定の結果，既知の TMB と一致した.乙かし溶解している電解生成物のほとんど が三級アミン化合物と推測され，その性状に大きな差が ないため分離しにくく, 口紙電気泳動法によってのみ分 離同定が可能であった．また分離同定と同時に各スポッ 卜を抽出し，紫外・可視吸収スペクトルによる同定も行 った．口紙電気泳動法による分離 および同定の 結果は Fig. 1 亿示すように主として青紫色のスポットと，その ほかの 3 つのスポットを認めた. 青紫色のスポットは $\mathrm{CV}$ および MV と一致し，そのほかのスポットはそれ ぞれ，TMB，ミヒラーヒドロール，テトラベースとー

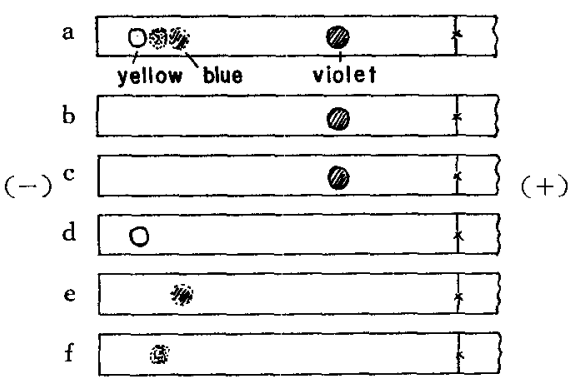

a: Product, b: CV, c: MV, d: TMB e: Michleis hydol, f: Tetrabase Medium : 30\% AcOH, Temp. : $20^{\circ} \mathrm{C}$

Volt. : $800 \mathrm{~V}$, Current: $0.4 \mathrm{~mA} / \mathrm{cm}$ Time: $180 \mathrm{~min}$

Fig. 1 Chromatograms of electrophoresis 致した.しかしクロマトグラムからもわかるように，こ の方法では青紫色色素が CV であるか MV であるか判 断ができなかったので，さらに化学的性状抢よび紫外・ 可視吸収スペクトルによる同定を行った。そこ結果，化 学的性状は CV の性質を示したが，CV と MV の可視 吸收スペクトルは $\lambda_{\max }$ がそれぞれ，589 593 $\mathrm{m} \mu, 583$ 〜 587 $\mathrm{m} \mu$ で非常に接近しており, しかも電解生成物の 青紫色色素の $\lambda_{\max }$ が $590 \mathrm{~m} \mu$ を中心わずかに変動す るため確認が困難であった。 そこで $\mathrm{CV}, \mathrm{MV}$ および 電解生成物の可視吸収スペクトルを種々の $\mathrm{pH}$ で測定し た.その結果 $\lambda_{\max }$ は Table 1 に示すような値とな り，CV に近く，電解生成物の青紫色色素は CV である と推定した．またさらに数回分の電解生成物中の青紫色 色素をあつめて精製し，同定用試薬と赤外吸收スペクト ル括よびロイ二塩基にしての融点などを比較同定し， CV であることを確認した。

Table $1 \lambda_{\max }$ at various $\mathrm{pH}$

\begin{tabular}{c|c|c|c|c|c|c}
\hline & $\mathrm{pH}$ & $\begin{array}{c}7.6 \\
(\mathrm{~m} \mu)\end{array}$ & $\begin{array}{c}5.4 \\
(\mathrm{~m} \mu)\end{array}$ & $\begin{array}{c}3.2 \\
(\mathrm{~m} \mu)\end{array}$ & $\begin{array}{c}1.5 \\
(\mathrm{~m} \mu)\end{array}$ & $\begin{array}{c}0.4 \\
(\mathrm{~m} \mu)\end{array}$ \\
\hline $\mathrm{CV}$ & 593 & 593 & 595 & 593 & 595 \\
$\mathrm{MV}$ & 582.5 & 584 & 584 & 583 & 585 \\
Product & 592 & 593 & 592.5 & 592 & 593 \\
\hline \multicolumn{7}{c|}{} \\
\hline
\end{tabular}

3 実験 結果 (Experimental Results)

\section{1 予備実酸}

白金電極を用以電解条件は Table 2 に示すように水 
分, 温度, 塩化水素濐度, 電流密度, 電気量を因子とし て，実験計画法の常法に従って実験を行った。その結 果, $\mathrm{CV}$ の生成に最む大きな影響を与える因子は塩化水 素濃度であり，他の電解条件を一定にしても塩化水素濃 度によって生成物が異なり， $\mathrm{CV}$ 生成のた如の塩化水素 の適性泿度は $0.15 \sim 0.5 M$ 上きわめて狭い範围である ことを認めた。

Table 2 Electrolytic oxidation

1) Condition

a) Electrode : Pt

b) Electrolysis: $3 \sim 30 \mathrm{~V}(2 \sim 0.4 \mathrm{~A})$

c) Conc. of $\mathrm{HCl}: 0.12 \sim 3.5 \mathrm{M}$

d) $\mathrm{H}_{2} \mathrm{O}$ content : $0.5 \sim 90 \%$

e) Temp.: $5 \sim 60^{\circ} \mathrm{C}$

2) Products
A) DMA $\frac{\mathrm{MeOH}, \mathrm{Pt}}{\mathrm{HCl} 1} \underset{(0.15 \sim 0.5 \mathrm{M})}{\mathrm{TMB}}$, Crystal violet
B) DMA $\underset{\mathrm{HCl}(0.5 \sim 2 M)}{\stackrel{\mathrm{MeOH}, \mathrm{Pt}}{\longrightarrow}} \mathrm{TMB}(0.5 \sim 1 M)$, Cation Radical (?) of TMB
C) $\mathrm{DMA}-\frac{\mathrm{MeOH}, \mathrm{Pt}}{\mathrm{HCl}(>2 M)} \rightarrow$ Chloranil, tar

\section{2 雷解条件の検討}

予備実験の結果，一定の塩化水秦濃度範囲ではある が，TMB と同時に CV が生成することを認めたのでさ らに各因子の収率におよぼす影響を検討した。ただ電解 生成物の分離定量が非常に困難なことから收率の比較注 $\mathrm{CV}$ 上 TMB 亿ついてのみ行った.

$\mathrm{CV}$ は可視部吸收スペクトルの $\lambda_{\max } 590 \mathrm{~m} \mu$ の吸光 度を用いたが， $590 \mathrm{~m} \mu$ における検量線は原点を通る直 線を示し，吸光係数 $1.04 \times 15^{5}$ であった．また TMB 注電解終了液中の沈殿の量収量とした。

1）水分の影響：Table 3 に示すような電解条件で水 分の影響を検討した結果， $10 \%$ 前後の水分を含む場合 に收率が極大走した。

Table 3 Influence of the water contained

\begin{tabular}{|c|c|c|c|c|c|}
\hline No. & $\mathrm{H}_{2} \mathrm{O} \%$ & Volt (V) & \multicolumn{2}{|c|}{ Yield of CV } & $\mathrm{TMB}$ \\
\hline 1 & 0.50 & $10.2 \sim 14.8$ & $0.701 \mathrm{~g}$ & $10.29 \%$ & $0.05 \mathrm{~g}$ \\
\hline 2 & 5.22 & $11.2 \sim 20.0$ & 0.702 & 10.30 & 0.5 \\
\hline 3 & 11.42 & $14.0 \sim 24.3$ & 0.961 & 14.10 & 0.6 \\
\hline 4 & 21.95 & $7.6 \sim 22.0$ & 0.809 & 11.85 & 0.7 \\
\hline 5 & 32.48 & $10.0 \sim 24.0$ & 0.461 & 6.76 & 2.0 \\
\hline 6 & 55.02 & $10.1 \sim 19.5$ & 0.069 & 0.56 & 2.75 \\
\hline 7 & 90.00 & $7.0 \sim 10.5$ & 一 & - & 2.45 \\
\hline \multicolumn{3}{|c|}{$\begin{array}{l}\text { Anode: } \mathrm{Pt}, \\
\text { Cathode: } \mathrm{Pt} \text {, } \\
\text { Temp. : } 50^{\circ} \mathrm{C} \text {, }\end{array}$} & \multicolumn{3}{|c|}{$\begin{array}{l}N \cdot N^{\prime} \text {-dimethylaniline } 6.1 \mathrm{~g} \\
\mathrm{fCl}-\mathrm{MeOH} 70 \mathrm{~m} l \\
\text { Current density } 4.0 \mathrm{~A} / \mathrm{dm}^{2} \\
\text { Conc. of } \mathrm{HCl} 0.204 \pm 0.002 \mathrm{~N}\end{array}$} \\
\hline
\end{tabular}

2）塩化水素濃度の影響 : CV が生成可能な濃度範囲 でその影響を検討した結果, Table 4 に示すように塩化
水素浱度が $0.18 M$ 前後のときに収率が極大を示した。 しかしこの点については DMA 濃度, 電気量などと相互 関係があることを注意すべきである。

Table 4 Influence of the conc. of $\mathrm{HCl}$

\begin{tabular}{|c|c|c|c|c|c|}
\hline \multirow{2}{*}{ No. } & \multirow{2}{*}{$\begin{array}{l}\text { Conc of } \\
\mathrm{HCl} \\
0.120 M\end{array}$} & \multirow{2}{*}{$\frac{\text { Volt. (V) }}{18.0 \sim 20.5}$} & \multicolumn{2}{|c|}{ Yield of $\mathrm{CV}$} & \multirow{2}{*}{$\frac{\mathrm{TMB}}{1.2 \mathrm{~g}}$} \\
\hline & & & $0.000 \mathrm{~g}$ & $0.00 \%$ & \\
\hline 2 & 0.152 & $16.5 \sim 19.0$ & 0.360 & 5.35 & 1.0 \\
\hline 3 & 0.184 & $13.6 \sim 18.5$ & 0.376 & 5.53 & 0.8 \\
\hline 4 & 0.230 & $11.5 \sim 18.0$ & 0.371 & 5.46 & 0.9 \\
\hline 5 & 0.284 & $11.2 \sim 28.5$ & 0.318 & 4.46 & 0.5 \\
\hline 6 & 0.347 & $9.2 \sim 17.7$ & 0.281 & 4.12 & 0.03 \\
\hline 7 & 0.483 & $6.8 \sim 11.5$ & 0.129 & 1.90 & 0.00 \\
\hline \multicolumn{3}{|c|}{$\begin{array}{l}\text { Anode: } \mathrm{Pt}, \\
\text { Cathode: Pt, } \\
\text { Current densit }\end{array}$} & \multicolumn{2}{|c|}{$\begin{array}{l}\text { DMA } 6.1 \mathrm{~g} \\
\text { Temp. } 30 \sim 40^{\circ} \mathrm{C} \\
\text { Current passed }\end{array}$} & \\
\hline
\end{tabular}

3）電解温度の影響: Table 5 亿示すように $50^{\circ} \mathrm{C}$ 付 近に収率の極大を認めた。

Table 5 Influence of temperature

\begin{tabular}{c|c|c|c|c|c|c}
\hline No. & $\begin{array}{c}\text { Temp. } \\
(\mathrm{C})\end{array}$ & $\begin{array}{c}\text { Conc. } \\
\text { of } \mathrm{HCl}\end{array}$ & $\begin{array}{c}\text { Volt. } \\
(\mathrm{V})\end{array}$ & \multicolumn{1}{c|}{$\mathrm{CV}$ yield } & TMB \\
\hline 1 & $10.5 \sim 12.0$ & 0.234 & $15.5 \sim 19.5$ & $0.000 \mathrm{~g}$ & $0.00 \%$ & $2.49 \mathrm{~g}$ \\
2 & 30.0 & 0.223 & $12.7 \sim 17.7$ & 0.306 & 4.49 & 0.60 \\
3 & 40.0 & 0.220 & $11.5 \sim 25.0$ & 0.477 & 6.94 & 0.85 \\
4 & 50.0 & 0.222 & $10.2 \sim 14.8$ & 0.701 & 10.29 & 0.05 \\
5 & 65.0 & 0.223 & $9.4 \sim 24.0$ & 0.483 & 7.09 & trace \\
\hline
\end{tabular}

Anode: Pt, $\mathrm{N} \cdot \mathrm{N}$-dimethylaniline $6.1 \mathrm{~g}$

Cathode: Pt, Current passed $2.8 \mathrm{AH}$

Current density $4 \mathrm{~A} / \mathrm{dm}^{2}$, $\mathrm{HCl}-\mathrm{MeOH} 70 \mathrm{~m} l$

4) 電流密度の影響 : Table 6 に示正よに $4.0 \mathrm{~A}$ / $\mathrm{dm}^{2}$ で極大を示し，さらに高くすると $\mathrm{CV}$ の収率が低 下するとともに，逆に TMBの収率が増加することを認 めた。

Table 6 Influence of current density

\begin{tabular}{c|r|r|r|r|r}
\hline No. & $\begin{array}{c}\text { Current } \\
\text { density }\end{array}$ & Volt (V) & \multicolumn{2}{|c}{$\mathrm{CV}$ yield } & TMB \\
\hline A $/ \mathrm{dm}^{2}$ & & & & \\
\hline 1 & 2.0 & $6.5 \sim 18.5$ & $0.226 \mathrm{~g}$ & $3.31 \%$ & $\operatorname{tar}(1.0 \mathrm{~g})$ \\
2 & 4.0 & $8.5 \sim 13.0$ & 0.565 & 8.25 & $0.24 \mathrm{~g}$ \\
3 & 8.0 & $19.6 \sim 48.0$ & 0.204 & 2.94 & 0.65 \\
4 & 12.0 & $27.0 \sim 72.0$ & 0.129 & 1.90 & 1.22 \\
\hline
\end{tabular}

Anode: $\mathrm{Pt}$, Conc. of $\mathrm{HCl} 0.214 M, \mathrm{HCl}-\mathrm{MeOH} 70 \mathrm{ml}$ Cathode: $\mathrm{Pt}, N \cdot N$-dimethylaniline $6.1 \mathrm{~g}$ Temp.: $50^{\circ} \mathrm{C}$, Current passed $2.8 \mathrm{AH}$

5) 電笑量の影響 : Table 7 に示すよらに, $0.05 \mathrm{M}$ DMA に対する最適電気量は $4.0 \mathrm{~A} / \mathrm{dm}^{2}$ で 9 時間電解 した場合に収率が極大を示した。

以上の結果加最適電解条件として $6.1 \mathrm{~g}(0.05 \mathrm{M})$ の DMA 塩化水素 $(0.18 M)$-メ夕ノール溶液 $70 \mathrm{~m} l$ (10\% 含水) に溶解し，白金電極を用い $50^{\circ} \mathrm{C}$ で電流密 度 $4.0 \mathrm{~A} / \mathrm{dm}^{2}$, 電気量 $3.6 \mathrm{AH}$ の条件で 再現性を検討 するため 5 回の電解を行った。 その結果, 収率は 17.87 
Table 7 Influence of the current passed

\begin{tabular}{|c|c|c|c|c|c|c|}
\hline No. & $\left|\begin{array}{l}\text { Current } \\
\text { passed }\end{array}\right|$ & $\begin{array}{l}\text { Conc. } \\
\text { of } \mathrm{HCl} \\
(M)\end{array}$ & Volt (V) & \multicolumn{2}{|c|}{ Yield of CV } & TMB \\
\hline 1 & $2.0 \mathrm{AH}$ & 0.230 & $11.8 \sim 21.5$ & $0.296 \mathrm{~g}$ & $4.35 \%$ & $0.35 \mathrm{~g}$ \\
\hline 2 & 2.8 & 0.226 & $12.5 \sim 15.5$ & 0.265 & 4.86 & 0.50 \\
\hline 3 & 3.6 & 0.244 & $12.0 \sim 21.6$ & 0.600 & 8.81 & 0.10 \\
\hline 4 & 4.4 & 0.226 & $12.0 \sim 16.8$ & 0.510 & 7.48 & 0.05 \\
\hline
\end{tabular}

〜17.92\% を示し，平均収率として $17.9 \%$ を示した。

\section{3 西極材料の検討}

$\mathrm{CV}$ の電解生成は単なる電極反応ではなく，しかも $\mathrm{TMB}$ と $\mathrm{CV}$ との生成は競争反応と予想されるので，電 極材料による影響をモリブデン・タングステン，グラシ 一カーボン㧍よびカーボン電極について検討した。

その結果,

1）カーボン電極：電解生成物が電極に吸着し，同一 条件下でもその收率が 10 32\% と再現性のある実験結 果が得られなかった。

2) グラシーカーボン電極 : カーボン電極と同様に電 解生成物の電極への吸着が著しく, しかも収率が大変低 加た。

3）モリブデン電極：実験計画法の基準に浻って，水 分(電極は塩酸に弱いため, 溶媒の含水量を小さくした) 塩化水秦湿度および電流密度を因子として電解を行い， 分散分析を行った結果, 含水量は订能な限り低く, 電流 密度は小さくすることに有意差が認められたが, 塩化水 素の水準間 $(0.15 \sim 0.5 M)$ では有意差は認められなか った。しかしこの実䟻下での最高収率も電圧 $1.6 \mathrm{~V}$, 塩 化水素濃度 $0.2 \mathrm{~N}$, 水分 $0.05 \%$, 電解時閒 12 時間で 18.3\% を示し，収率の增加はのぞめなかった。

4）タングステン電極：モリブデンの場合上同様の因 子で実験計画法に沿って最高条件を求めて電解矢験を行 ったが，最高收率 $17.5 \%$ で，この場合も期待されるほ どの収率の増加は認められなかった。

\section{4 考察 (Discussion)}

\section{1 トリフェニルメタン系色素の生成}

トリフェニルメタン系色素 CV が DMA の酸化によ って生成した.しかし同一溶液条件でまったく電流を流 さない空実験からも微量の（電解した場合の $1 / 5000 M$ ) の CV が得られることおよび電解生成物中にテトラベー ス, ミヒラーヒドロールが存在することから, CV の生 成機構は特異的な電極反忘ではなく, Fig. 2 亿示すよう な溶媒自身の陽極酸化と 2 次的な化学反応過程および陽 極酸化過程を経て起るものと推測した。
(I) 1) $\mathrm{CH}_{3} \mathrm{OH} \underset{+\mathrm{O}}{\stackrel{-2 \mathrm{e}}{\longrightarrow}} \mathrm{CH}_{2} \mathrm{O}+\mathrm{H}_{2} \mathrm{O}$
2) $2 \mathrm{ON}\left(\mathrm{CH}_{3}\right)_{2}+[\mathrm{II}] \stackrel{[\mathrm{II}]}{-\mathrm{H}_{2} \mathrm{O}}\left(\mathrm{CH}_{3}\right)_{2} \mathrm{NOC} \mathrm{CH}_{2}-\mathrm{ON}\left(\mathrm{CH}_{3}\right)_{2}$

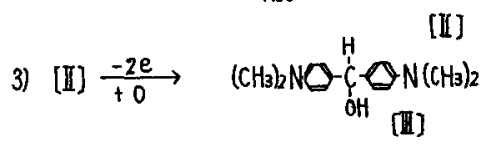

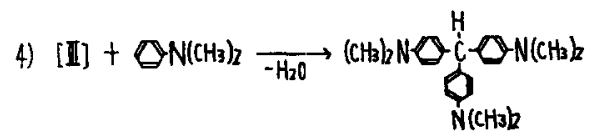

[IV]

5) [IV] $\frac{-2 e}{+Q^{-}}\left(\left[\mathrm{CHWH}-\mathrm{O}=\underset{\mathrm{C}}{\mathrm{C}}=\mathrm{CH}_{3}\right)_{2}=\mathrm{N}^{+}\left(\mathrm{CH}_{3}\right)_{2}\right) \mathrm{Ql}^{-}$

(II) 1) $\left\{\begin{array}{l}\text { A) } \Delta \mathrm{N}\left(\mathrm{CH}_{3}\right)_{2} \stackrel{-\mathrm{e}}{\longrightarrow} \cdot \mathrm{ON}\left(\mathrm{CH}_{3}\right)_{2} \\ \text { B) } 2\left(\mathrm{CH}_{3}\right)_{2} \mathrm{NO} \cdot \longrightarrow\left(\mathrm{CH}_{3}\right)_{2} \mathrm{~N}-\mathrm{OON}\left(\mathrm{CH}_{3}\right)_{2}\end{array}\right.$

\section{2) A) $\triangle \mathrm{N}\left(\mathrm{CH}_{3}\right)_{2} \stackrel{-2 E}{\longrightarrow}+\mathrm{O}-\mathrm{N}\left(\mathrm{CH}_{3}\right)_{2}$ \\ B) $+\mathrm{O}-\mathrm{N}\left(\mathrm{CH}_{3}\right)_{2}+\mathrm{ON}\left(\mathrm{CH}_{3}\right)_{2} \rightarrow\left(\mathrm{CH}_{3}\right)_{2} \mathrm{NOON}\left(\mathrm{CH}_{3}\right)_{2}$}

Fig. 2 Formation mechanisms of $\mathrm{CV}$ and TMB

1）中心炭素源：もし中心炭素源が Fichter らの報 告 ${ }^{2)}$ と同様にテトラベースの生成過程で DMAのメチル 基の一部が解離したものであるとすれば，生成する色素 は $\mathrm{CV}$ と $\mathrm{MV}$ との混合物となるはずである。しかし著 者らの実験では CVのみ得られ，しか子溶媒をエタノー ルにした場合にはトリフェニルメタン系色素が得られな かった。このことから本実験の場合はメタノールの陽極 酸化でホルムアルデヒドが生成し，これが中心炭素源に なったものと推定した.

2) 酸素源：ホルムアルデヒド（I）とミヒラーヒド ロール（III）の生成には酸素を必要とするが, 窒菜がス で電解液中の脱酸素を行いながら電解しても CV が得ら れること, および含水量 $10 \%$ 前後の場含に収摔が極大 を示すこ上から，電解液中の水分が酸素源であるうと推 測した.

3）脱水縮合反応: テトラベース（II）とロイコ塩基 (IV)の生成には脱水縮合怔行われねね゙ならないが, 酸 素源として必要な水分も含水量が $10 \%$ 前後から多くな ると逆に CV の收率が低下することから，CV の生成機 構の中に塩化水素触媒に上る脱水縮合反応があると推測 した.

4）化学反応：CV の收率蛙電解時の反応温度を高く すると増加し，電流密度をあまり上げると減少すること からも， $\mathrm{CV}$ の生成機構は篻なる電極反匛ではなく，2 次的な化学反店過程を含み，しかむ化学反応が律速段階 になっていると推定した。 
5） TMB の生成：CV が生成する丽解条件では， Table 3〜7 にも示したよ5に TMB が同時に生成し た。しかも条件によってまったく浊者の収率の增隇が逆 になる場合があり，またDMAにホルムアルデヒド(I) を添加して加熱かくはんするだけでもテトラベース（II） が生成することから，この電解反応はメタノールの電解 酸化と, DMA の電解酸化との競争反応であると推定し t.

DMA の酸化による TMB の生成機構は Fig. 2 に示 したように2つの方法が推測されるが， $\mathrm{Seo}^{7} ら$ らこの 二量体化がラジカル反応かイオン反応か不明だと報告し ている.

\section{2 塩化水素の影䧺}

電解生成物に最も大きな影響在与える月子は塩化水素 であり，しかもその適用範囲がせまく，0.15 0.5M 範囲では前述のよらに CV よ TMP が生成した。しか し $0.5 M \sim 2 M$ の範用になると電解液の色注 CV 生成 時上同様に緑色までは変化するが，れ机上の色の変化

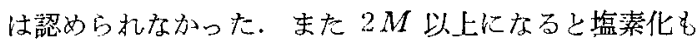
伴いクロルアニルが生成することを認めた。そこで生成 物の不明な $0.5 M \sim 2 M$ の筑囲での生戊物である緑色 電解液について検封した。

1）化学的方法：塩化水素が縮合反心忍の触媒としての み働くとすれば，塩化水素濃度が $0.5 \mathrm{M}$ 以上でも $\mathrm{CV}$ か $\mathrm{TMB}$ が生成するはずでまり，しかも CV の溶液は $\mathrm{pH} 3.0$ 以下では緑色を呈することから CV の可能性も ある、そこでこの緑色電解液にアンモニアガスを吹き远 み中和したが溶液は紫色とならず青色呈し，さらに一 昼夜放置する上変色してかっ色上なった. 次に色の変化 から中間体を予想してさらに電解を続けたが，CV 湟 られなかった.しかし $0.5 M \sim 1 M$ の間では TMB が わずかに得られた。

2） ESR：緑色電解液は一冝夜で分解して赤かっ色上 なりまたアルカリで容易に還元されることから不安定 なラジカルであることが推測され，乙かもこの電解にお ける電解液の変化が Nayler ${ }^{3)}$, Mizoguchi $^{8}$ ) らの電解酸化 の場合と非常に類似しており，両者の推定しているTMB が 1 電子酸化を受けて生成するカチオンラジカル゙が生 成していることも予测された，また Mizoguchis らは DMA の酸化によって TMB のカチオンラジカルが生成 するのはラジカルイオン反岕ではなく，イオン機構だよ 報告しているが, ESRによる確認がなされていないので 著者らは ESR 在利用してラジカルの存否を検討した。

ESR の測定は内径 $1 \mathrm{~mm}$ の石英試験管の陽極付近が 3〜 $5 \mathrm{~mm}$ 変色するまで電解し，ただちに测定，Fig. 3

$\left.{ }_{* 1}\left(\mathrm{CH}_{3}\right)_{2} \mathrm{~N}<->-\mathbb{Z}_{-}\right\rangle-\mathrm{N}\left(\mathrm{CH}_{3}\right)_{2}$
に示すようなデータ劣得た．しかしラジカルの消失速度 が早いためか微細構造の検討ができるほど明確なデータ は得られず, DMA のラジカルなのか TMB のカチオン ラジカルなのか確認することができなかったが，DMA の電解酸化によって何らかのラジカルが生成しているこ と苍認めた。

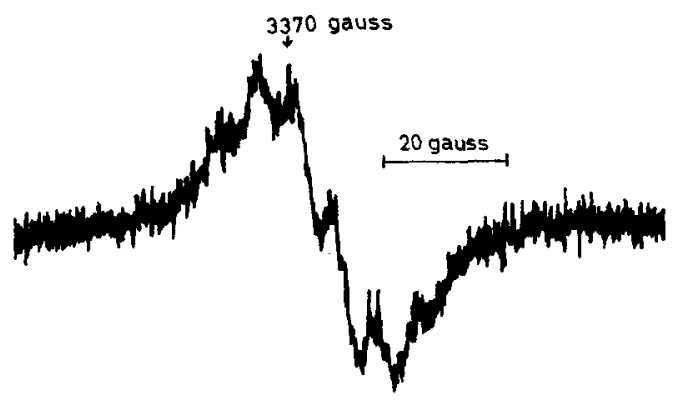

Sample DMA in HCl-MeOH ( $30 \mathrm{~V}$ ); Field $3,370 \pm 100 \mathrm{G}$ Gain $4 \times 100$; Response 0.3; Mod. width $0.6 \mathrm{G}$, Power att. $19.3 \mathrm{~dB}$

Fig. 3 ESR spectrum of electrolyte (DMA)

$$
5 \text { 総 括 (Summary) }
$$

1）塩化水素一メタール溶液中で DMA を電解する と塩化水秦濃度が $0.15 \sim 0.5 \mathrm{M}$ の範围で TMB ととも にクリスタルバイオレットが生成することを認めた。

2) 色素の生成機構は単なる電極反応のみではなく2 次的な脱水縮合反応を伴い，この反忘が律則段階である こと䘮認めた。

3）クリスタルバイオレットの生成とテトラメチルベ シジジンの生成とは競争反応であり，クリスタルバイオ レットの最高収率は約 $18 \%$ 程度で，これ以上の向上は 困難であることを铝めた。

終わりに，本研究に除し 研究費の補助学受けた旭硝子工業技 術奖励会, 本研究にご助言を頂いた 熊本大学薬学部赤塚政美助 教授, ESR 測定を行って頂いた熊本大学工学部山口博子助手拉 よび本実験の一部を担当して下さった近藤繁美氏，東恆夫氏に 合せて感謝の意を表します。

$$
\begin{aligned}
& \text { (Received April 26, 1971) } \\
& \text { 文 献 }
\end{aligned}
$$

1) W. Lob, Z.Elektrochem. T, 579 (1901)

2) F. Fichter, E. Rothemberger, Helv. Chim. Acta 5, 166 (1922).

3) F.T. Naylor, B.C. Saunders, J. Chem. Soc. 1950, 3519 (1950).

4) J.W. Eastman, G. Engelsma, M. Calvin, J. Am. Chem. Soc. 84, 1339 (1962).

5) J.R.L. Smith, R.O.C. Norman, W.M. Walker, J. Chem. Soc. B 1968, 269 (1968).

6) N.L. Weinberg, T.M. Reddy, J. Am. Chem. Soc. 90, 91 (1968).

7) E.T. Seo, R.F. Nelson, J.M. Fritsch, L.S. Marcoux, D.W. Leedy, RN. Adams, J. Am. Chem. Soc. 88, 3498 (1966).

8) T. Mizoguchi, R.N. Adams, ibid. 84, 2058 (1962). 